\title{
Preference of media politics and beginner voter trust in Surakarta
}

\author{
Erwin Kartinawati \\ Universitas Sahid Surakarta, Indonesia \\ Email: erwin.kartinawati@usahidsolo.ac.id
}

\author{
Andrik Purwasito \\ Universitas Sebelas Maret, Indonesia \\ Email: andrikpurwasito@staff.uns.ac.id
}

\begin{abstract}
The Indonesian Presidential Elections of 2014 and 2019 indicated the behavioral changes in mass media, especially that of private television. The involvement of media owners in the political arena can influence the content of most journalistic broadcasts. Therefore, this study aims to determine the perception of student voters in Surakarta on media houses with political preferences. This might be because the media owner is actively supporting a political party or a particular candidate. Furthermore, if the media is under the influence of politics, how can voters have trust in the information dissipated, especially during elections. The data obtained for this study was through the distribution of questionnaires to college students aged 17-25 years that are voting for the first time. Most of the respondents stated that their political choices are not necessarily influenced by the media. The belief in the media is not directly related to political preferences but depends on the content or what is conveyed to the public. However, the involvement of media owners in politics also undermines public trust in the content of the media, especially about political news. The public believed that the media would not be able to act neutrally and objectively in their coverage as long as it had affiliation to a particular political party.
\end{abstract}


Keywords: Beginner Voters, General Elections, Media Owner, Political Preferences, Trust.

\section{Introduction}

Indonesia's presidential elections of 2014 and 2019 indicate changes in the mass media's behavior, especially that of private television. The results of the 2014 presidential election, influenced the media's content, as clearly indicated on Metro TV and TV One. This change was new to the world of Indonesian journalism, especially in the reform era after the collapse of the New Order's power. The shift in media coverage first occurred in Indonesia after the rise of democracy, when television stations blatantly became mouthpieces and propaganda tools for political agents. Consequently, television took the side of whatever candidate it sided with, as in the 2014 presidential election, Metro TV and TV One outrightly supported certain parties. Furthermore, the news coverage of both media houses revealed a partiality towards one of the candidates. Even after the end of the election, both media still positioned themselves as supporters of one of the contestants who had previously competed for president. Metro TV sided with Joko Widodo and Jusuf Kalla (Jokowi-JK) while TV One supported Prabowo Subianto and Hatta Radjasa (PrabowoHatta). The support offered to these candidates could be seen from the news content and the way both media presented the news. For Metro TV, it was support for the behavior, decisions, programs of the Jokowi-JK administration, while TV One was the discrediting of the opposition. However, the allegiance of these media houses was not only to presidential candidates but to political parties as well.

That situation not only brought out the complaints but also protests from many parties both the community and the government regarding the unprofessional conduct of the media. The website change.org, for example, had a platform where complaints could be made and sent to the Ministry of Communication and Information (Kemkominfo) and the Indonesian Broadcasting Commission (KPI) which contained petitions to revoke Metro TV and TV One broadcast licenses (change.org, 2014). Those petitions were signed by more than 50 thousand people. Consequently, the KPI sent some reprimands to the two broadcasting institutions regarding the neutrality of the programs broadcasted during the election, even asking for an evaluation of both media's broadcasting permit (IPP) (Az, 2014). Furthermore, the Press Council 
also received a request to impose sanctions on the media houses regarding the number of press company leaders who later became leaders of political parties (www.detik.com, 2017). Consequently, the government through the directives of the KPI and the Ministry of Communication and Information finally asked several suspicious media groups to sign seven commitments as a condition for a permit extension. Therefore, that signing is viewed as a correction form on the media's behavior. One point in the commitment is the promise to maintain media neutrality, which is free from all kinds of political interference or pressure from capital leaders (Laksono, 2016). However, the agreement failed to hold, as the 2019 presidential election, still showcased instances of political favoritism among media groups, most notably, the groups listed above.

Surya Paloh, a major stakeholder in Metro TV is the general chairman of the Democratic National Party (Nasdem), while Abu Rizal Bakrie, the owner of TV One, is the general chairman of the Golongan Karya party (Golkar). During the 2014 presidential election, both media groups were in opposition because Nasdem formed a coalition with several other parties which supported Joko Widodo-Jusuf Kalla, while Golkar formed another coalition supporting Prabowo Subianto-Hatta Rajasa. Therefore, the topic concerning the most appropriate candidate for president was the main debate enjoyed by the public during the election period.

In the 2019 Presidential Election, the media's behavior did not change, as it still displayed its political preferences toward candidates for the 2019 Presidential Election. However, the support displayed during this election was not as brazen as that of 2014. Due to all of that, the expectation that citizens will obtain coverage of electoral proceedings free of bias seemed distant. The violations of the media code of ethics relating to the concept of independence, neutrality, and objectivity, now seemed common. This situation is interesting because when the media is given the widest possible freedom in the dissemination of information, without fear of dismissal as in the era before the reform, the press does not act neutral by binding themselves to politics. In the era before the reformation (before 1999), neutrality was something that was very expensive and could not even be obtained due to the influence of the government at that time. Through the Ministerial Decree (SK) number 29/SK/M/65 dated March 26, 1965, the press was obligated to associate itself with one political party, such as Golkar or any other mass organization. Furthermore, the editorial and management staff must be the party's elect (Hill, 2011). That decree was made on the pretext of maintaining national security from domestic and foreign threats 
and at the same time overseeing the integrity of the nation. Because of that, the press was required to side with the government, political parties and, certain organizations. Furthermore, breidel or closure of a media company became a consequence for the groups that did not comply with the regulations at that time (Yandry, 2017); (Surjomiharjo, 2002). However, during the reform era, the press was given full freedom. There are no longer breidel threats or any other forms of barriers to press efforts regarding the dissemination of information to the public. Currently, freedom of the press is legally supported by law number 40 of 1999. However, when the press is given complete freedom, it usually ties itself with one of the political parties or other stakeholders.

This study was conducted to evaluate media behavior as mandated in article 52 of the Broadcasting Law No. 32 of 2002 that the public is obliged and has the right to control media content. Public control is important and also needs to be carried out by analyzing channels used by the media. Information is public property that must be used for the prosperity of the people and not for the benefit of certain groups (1945 Article 33 of Law). This public control also becomes important considering the power possessed by the media in shaping and influencing public opinion. The digital era makes the management of the media a bit difficult, as the audience becomes wider, and no longer limited by broadcast coverage and other geographical and demographic conditions (Butler, 2019). Television today can be enjoyed not only through a screen but online, through the use of social media. Today, information is easier to reach the public because television shows can be seen easily without constraints on airtime. Furthermore, through social media like YouTube, Instagram, Facebook, information can be copied and pasted (click and share) through private and group chat services, WhatsApp, and others. This situation, sure, not only occurs in Indonesia but is also global. This phenomenon does cause new problems in the form of conglomeration, convergence, and media consolidation (Mcquail, 2011). They are just that the problems that are not being discussed in this paper.

Studies related to public trust in the media, or that have similarities to this study have existed before. Some of them were conducted by Widiastuti (2016) entitled "Media Ownership and Democracy in the Digital Information Era"; then Widarini and his colleagues with titled "Public Trust in the Mainstream Media Press" (2019); Wasisto Raharjo Jati (2013) with the title "Media And Political Persuasion: The Role Of Media In Indonesia Presidential Campaign 2001-2009", and Herieningsih Widowati (2014) titled "Exposure to Mass Media Coverage and Level of Public Trust in Jokowi's Competence as a 
Leader To Public Interest In Choosing Jokowi as Capres”. However, this article has different from previous studies, at least with four titles as stated above. Widiastuti's writing highlighted the concentration of media ownership in Indonesia, thus showing control over the behavior and content of the mass media, including during the election period. Furthermore, Widarini's writing, which was the result of research in cooperation with the Press Council, discussed the flood of information in the digital age, precisely impacting public trust in the mainstream media. That was because the internet platform media put more forward the speed and orientation of viewers known as clickbait journalism. Wasisto's study underlined the role of the media as a creator who could engineer all political-related news including elections. Framing the media still placed the public as a passive object that is easily manipulative. Last was Widowati's study that mentioned that media exposure could indeed direct public choice to a certain presidential candidate but did not have an impact on increasing public trust in the image built by the media. The conclusion was dug from the opinion of the people of Sendangmulyo Semarang Central Java about the news exposure of Jokowi as a presidential candidate in the 2014 election. The four studies above discussed that media content could be influenced by media ownership. It's just that, what the public's opinion of the media affiliated with political parties looks like and whether it has implications for public confidence in the press, has not been discussed, especially the group of novice voters. Thus, the results of this study can be used as a basis of decision-making for both mass media and related stakeholders. For the media, it is related to public trust which is the main key to the continuity of media organizations. Furthermore, without trust, the public is reluctant to watch, which in turn has an impact on ratings and then advertising revenue. However, for stakeholders, it is related to the government (Kemkominfo, KPI) as it concerns the importance of returning the press to its original spirit of idealism. The history of the press in Indonesia is built on idealism, which in turn gives the media its function as educators. However, without control, the press can be dangerous because it can turn to tyranny by forming truths based on the interests of the authorities.

\section{Literature Review}

\section{Media normative theory}

Media normative theory guides what the media should do. This theory is a behavioral guide for the media concerning their power in spreading messages 
and the impact they can have on society. How the media should behave has been regulated in certain terms which are known as journalistic principles. In Indonesia, the basic principles of journalism can be seen in the Press Law No. 40 of 1999, the Journalistic Code of Ethics, the Broadcasting Law No. 32 of 2002, and the Broadcasting Code of Conduct and Broadcast Program Standards (P3SPS). Journalistic principles emphasize how the media should behave, regarding the obligation to be independent, to produce accurate, balanced news, and not with bad intentions.

\section{Agenda Setting Media and Public Opinion}

Mass media including television can be used as a tool to shape and influence public opinion. The media has its agenda to be presented to the public by highlighting certain issues. To stand out, issues must be packaged and framed attractively to encourage the formation of public opinion (Tamburaka, 2012). The theory of agenda-setting media shows that the reality that circulates in society is the result of media construction, one of which is through the news. The media make efforts to control the reality that occurs in society. The media constructs as well as directs how we should think and even act. In the context of the 2014 presidential election, we could see that the media especially Metro TV and TV One, had an important role in making discourse distributed in society through the construction of political news.

\section{Media and The Influencing Factors}

The content of mass media, including television, is strongly influenced by various internal and external pressures (Mcquail, 2011). The influence from within the media organization is the interference of parties: (1) Management, (2) Media professionals (human resources), (3) Technical/technology support. Meanwhile, external factors that influence media content are economic and socio-political pressures. Economic pressure consists of: (1) Competitors, (2) News/information agencies, (3) Advertisers/sponsors, (4) Owners, (5) labor organization. Meanwhile, socio-political pressure includes (1) Political / legal control, (2) Pressure groups, (3) Other social institutions. Besides, several other forces also influence, namely the supply of events, information, culture, channel distribution, audience, interests, needs. Through those factors, we can see the kind of influence that affected the news broadcast by Metro TV and TV One during the 2014 presidential election. From factors above, we can get an idea of why there is bias in mass media reporting and why the mass media uses its power for certain things. 


\section{Methods}

The purpose of this study is to explore public perceptions relating to changes in the media's behavior concerning politics. Political preferences can influence the quality and objectivity of information passed to the public which will, in turn, affect the public's trust in the media. The research object in this paper comprises young voters who have only participated in the 2014 and/or 2019 presidential elections. In Indonesia, the right to vote in an election is granted to citizens that are 17 years old or older, and or have married (Indonesian General Election of Law, 2017). This study does not include all young voters but only a section of the community, namely students. These were mostly undergraduate students because their ages ranged from 17-25 years. Students were chosen as objects of study because of the assumption that the majority of undergraduates are beginner voters, therefore still have high standards regarding the ideal leader. The political preferences of young people are usually not much influenced by personal sentiment, race, ethnicity, religion, and other matters regarding their political experience. Data were obtained through questionnaires. However, due to the Covid-19 pandemic and the call for social distancing, the questionnaire was not distributed directly but through Google Forms for ten days, from June 6th to 15th, 2020. The data was processed descriptively to suit the issues that were to be explored as mentioned above.

Behavioral approaches are used to help understand the problems in this study. The behavioral approach focuses on learning and socialization, motivation, perception, attitude to the authority, and other considerations (Ataya, 2018). In understanding voter behavior, several approaches are often used, namely sociological, psychological, and rational approaches. The sociological approach emphasizes the importance of things like socioeconomic status such as education, type of work, income, religion, ethnicity, also about geography. The psychological approach relates to the value of environmentally derived norms including parenting, then, a rational approach concerning the logic (Visser, 1998).

\section{Result and Discussion}

The 246 respondents in this study, came from several universities in Indonesia, especially in the Surakarta area, including Surakarta Sahid, Slamet Riyadi, Veterans Bangun Nusantara Sukoharjo, Boyolali, and, Sebelas Maret 
University. Students from the Muhammadiyah University of Surakarta, Open University, and Indonesia Polytechnic were also involved. Data revealed that $77.6 \%$ of the students used their voting rights in the 2019 Presidential Election (191 people) and only 22.4\% (55 people) used their voting rights in the 2014 Presidential Election. Because the majority of respondents used their right to vote in the 2019 Presidential Election, 65\% of the young voters claimed not to have watched political news shows, especially relating to the 2014 presidential election both on Metro TV and One TV. Political news, especially about the Presidential Election, was viewed by the respondents during the 2019 Presidential Election. The respondents watched the coverage on both television channels, Metro TV news viewers were $78.5 \%$ and TV One was $80.5 \%$.

Therefore, from the total respondents ( 246 people), $72.8 \%$ or 179 people felt that both stations were not neutral in their reporting because they had a concern for one of the candidates and/or for their support group. This could be observed from the manner of reporting and how information about the candidates is conveyed to the public.

A majority $(52.8 \%)$ of young voters believe that the media content concerning a candidate depends on which political parties the media owner supports. Those who expressed doubts (35.4) and felt there was no connection (11.8\%), did not like political news and therefore did not follow the update of news or political information. Furthermore, these individuals prefer answers that are considered "safe". There is an interesting thing to note, however, the majority of respondents that felt the media's leadership affected the objectivity of information also stated that it was not a problem if the media had political preferences that affected the support for one candidate (38.2\%). The rest stated that they did not agree (36.2\%), 20.7\% agreed, and $4.9 \%$ did not care.

The political preferences of the media during the presidential election according to the majority of respondents did not matter to them. However, this majority gave a firm note that it is not alright if the reporting is influenced by a candidate or party (40.7\%). The rest stated firmly disagree (25.2\%), $23.2 \%$ (normal), 5.7\% (agree only), 5.3\% (did not care). Therefore, this group, when watching the news on television stations influenced by a candidate, prefers to switch channels (62.6\%). Those who keep watching $37.4 \%$ do so to know the latest news and also want more information before they choose any candidate. However, those who choose to change channels tend to favor candidates who are supported and vilify the opposition, therefore there is an unfair assessment of one of the candidates competing in the election. 
Although the media does play a part in shaping opinions, young voters are not fully affected by the picture painted by the media. Only $26.4 \%$ of respondents claimed that the choice of candidate was due to the influence of media coverage. The rest or $73.6 \%$ stated that media coverage did not affect the decisions made in the elections. In choosing potential leaders, compatibility in vision and mission are the main determining factors (79.7\%). Other factors are the influence of parents, friends, ethnicity, region, religion, political parties, and even random choice. Furthermore, due to political preferences, young voters have realized that the media paint the truth about supported figures to garner support for candidates. Therefore, most of these voters claim not to be completely convinced by the imagery shown in the media.
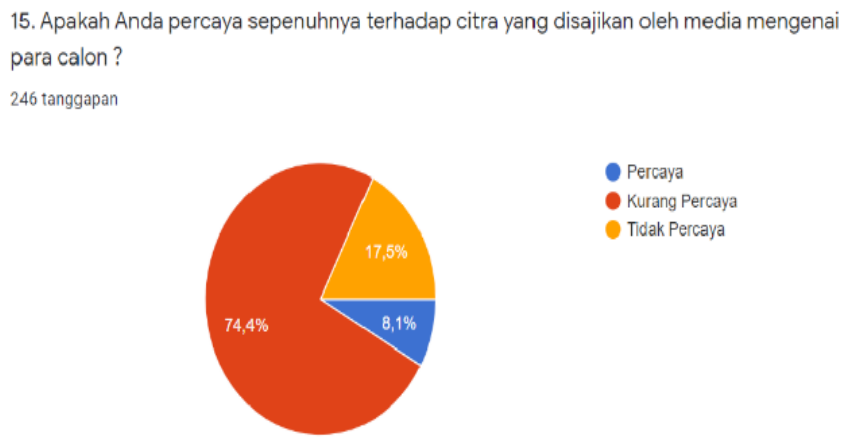

Kurang Percay

Figure 1: The perception of beginner voters about the candidate's image in the mass media. Blue colour showed about believe perception, red showed rather perception, orange showed not believe perception.

Source : Research Data

The media houses that have political preferences turned out to influence the decisions of the young voter by the content delivered to the public. However, the number of people influenced is not large, the remaining majority stated that it was still able to examine the contents of the news. The young voter believes that having political preferences is fine as long as it does not affect the content or independence of the media. Consequently, the majority of young voters expect the media to remain neutral in reporting the facts to the public, and not be affected by anything.

The results of this study indicate that young voters have political choices that are not easily influenced. This is made possible by the student's educational 
background and exposure to very diverse information. That is in line with some research results that mention if the level of education affects the low participation rate in elections, although it is many debates, in this case, whether it is the main determinant or only companion (Mayer, 2011); (Persson, 2015); (Kolstad, Ivar; Wiig, 2016). This article is not to discuss the issue of education debate as a determinant in public political participation but the results of this study at least show if educational background and knowledge are decisive in the decisionmaking of novice voters in the general election. Regardless of all, throughout the years, television has become the main medium of information propagation and no other channel seems capable of attracting public attention in the same scope and intensity as television. Television is a place where family members spend the most time but do not seem to notice (Heryanto, 2015). Television is a favorite because apart from it being cheap, fast, and able to provide visual entertainment, it can combine the sophistication of visual technology and audio engineering. This media has its place in society because seeing is believing (Suwardi, 2006). Television as a visual media can present thoughts and ideas involving movements that cannot be portrayed by print media and can combine visuals, sounds, drama, movements, colors and, music simultaneously making it able to attract the audience continuously to the messages conveyed. This media form is also able to eliminate the problem of distance and time by presenting live events (Biagi, 2010). More than that, television is also able to bring back memories of the past that cannot be found directly by members of the public. Because of its ability, it is even called able to overcome the problem of amnesia in culture (Edgerton, Gary Richard; Rollins, 2001). However, after the emergence of the internet, the source of information became more diverse and abundant. That is the case with young voters, especially those who become respondents in this study. These voters take information from various sources, then filter and use what is considered to be in line with their needs. However, this is different from the results of several studies which indicate that the decision of the novice voters in choosing presidential candidates is based on the influence of parents and irrational basis such as a sense of admiration for the candidate as well as forms of material stimulation, including gender, as well as the age (Nur, Raoda; Taufik, Ahmad; Tahir, 2015); (Alelaimat, 2019); (Kurtbal, 2015).

The results of this research reveal that the newbie voters in Surakarta already have political awareness and can choose candidates by themselves. However, these results indicate that the lack of information is connected to the media's power in being able to influence public opinion. This is more due to 
the factors of the younger generation who tend to dislike political matters less. The issue of young people who don't like political issues is also a phenomenon not only in this country but also in other countries to influence them in deciding potential leaders in the electoral process. In Australia, for example, the involvement of the younger generation in politics is low enough to be seen from their passiveness in the search for information. They also tend to still rely on information from old media, especially television and newspapers, in providing political information needs (Winchester, Tiffany M.; Binney, Wayne; Hall, 2014). Article 5 of the Broadcasting Law No. 32/2002 states that broadcasters are directed to provide true, balanced and, responsible information. Article 36 also states that the contents of a news report must be neutral and must not prioritize the interests of certain groups. Consequently, the broadcasting code of conduct and broadcast program standards (P3SPS) in chapter VII expressly states that broadcasters must maintain independence and neutrality of broadcast content in every program as stipulated in article 11 regarding the protection of public rights. Furthermore, this is also reinforced in article 22 which states that broadcasting is required to maintain independence in the production process of journalistic broadcast programs and is not to be influenced by external or internal parties, including investors or broadcasting institution owners.

Media behavior must be regulated because media products are not without impact, one of which is in terms of the shape of public opinion and behavior. The way the media chooses news and how to present information to the public is not something neutral but full of ideological views. What the media does can direct audiences to how they should understand reality. Gaye Tuchman even asserted that the way the mass media constructs facts into news can have a tremendous impact. One of them is as a means of achieving power because an event can give a certain image to an actor (Nimmo, 2000). News is not limited to the way the media in carrying out information functions, but more. News is not purely a channel for delivering messages but also a political tool to achieve power. Barker (2014); Pawito (2009); and Mursito (2012) asserted that news was not a mirror of reality but a representation of the results of selection and construction results that formed reality. In the context of the news of Metro TV and TV One during the 2014 and 2019 presidential elections, it showed that news was no longer merely information that was in the public interest but had also been constructed in such a way for certain interests or purposes, including to achieve and support power. The basic principles of journalism were no longer held and applied purely. Media showed the shift of its basic functions clearly 
and visible from supposed as a channel or media (tool) information/news, into another tool. This is called the abuse of media power abuse.

Misuse of media power/power relates to aspects of ownership that later impact content (Mcquail, 2011). The media is no longer a value-free channel but has changed as a tool for gaining importance. The way used one of them is through the construction of reality against the content of the news. Television uses its power as a source of crowd outreach quickly and en masse, by disseminating information/news based on aspects of personal/group interests. From here, this study argued that Metro TV and TV One had used their power to achieve political goals in this case winning one of the presidential candidates. That was interesting because power has a big part in shaking up the independence of the media in this case is private television. Power in essence is indeed the basis of human life goals to profit from the results of the transaction process with other parties (Purwasito, 2011). Power is the ability to govern or control (Suseno, 2002). Television is a media that uses the public domain (broadcast spectrum) so it should be if television in the implementation of broadcasts is also oriented in the public interest (Broadcasting Law No. 32/2002, Chapter III Ps.1). But in reality, we see the orientation of television has been different by putting aside the principle of impartiality, blatantly presenting itself as a partisan medium (media affiliation). Media independence is needed as a control of power given the power of the media in disseminating information and influencing public opinion. That's why the media is also referred to as a pillar of democracy (Gans, 2004). Unsupervised, power would be tyrannical and the media could be one effective tool for creating "truth" based on the regime's version of power by disregarding public rights (Kovack \& Rosenstiel, 2001). This is also the basis of why media behavior should be regulated based on the basic principles agreed upon. The way Metro TV and TV One in the presidential election news can not be used as a model of political education that is right for the community, especially for novice voters.

\section{Conclusion}

The results reveal that the involvement of media owners in the political world has an impact on the content that will be disseminated especially during the election period. This influence can be felt again when a political party lead by a media owner joins in or gives support to one of the candidates in the election. The study was conducted on student voters in Surakarta. Therefore, 
the political preferences of the media are difficult to avoid when the media owner or main investor is active in politics. According to the young voter, the political preference of media houses is of no consequence, as long as it does not affect the news content. The media is still expected to be neutral even if there is some involvement of media owners in the political world. Consequently, public trust depends on the content delivered to people and should not be influenced by the media's political preferences. The decision to vote for a political candidate among students in Surakarta was not influenced by the media. The picture painted by the press only accounts for a small part while the main determining factor is compatibility with the vision and mission that is conveyed to the public by the candidate. The study also concluded that media literacy linked to general elections for young voters needs to be carried out to provide an understanding of the press's behavior when it comes to applicable laws and codes of ethics.

\section{References}

Alelaimat, M. S. (2019). Factors affecting political participation (Jordanian universities students' voting: field study 2017-2018). Review of Economics and Political Science. https://doi.org/https://doi.org/10.1108/REPS-052019-0072

Ataya, I. H. (2018). Behavioralism. In Oxford Research Ecyclopedias. Oxford Library. https://oxfordre.com/view/10.1093/ acrefore/9780190846626.001.0001/acrefore-9780190846626-e-376/ version $/ 0$ ?print $=$ pdf

Armaya, T., Herieningsih, S. W., Pradekso, T., \& Yulianto, M. (2014). Terpaan pemberitaan media massa dan tingkat kepercayaan masyarakat pada kompetensi Jokowi sebagai pemimpin terhadap minat masyarakat memilih Jokowi sebagai Capres. Interaksi Online, 2(4), 1-11. https:// ejournal3.undip.ac.id/index.php/interaksi-online/article/view/6608

Az. (2014). KPI minta Kemkominfo evaluasi IPP Metro TV dan TV One. 07-04-2014. https://kominfo.go.id/content/detail/4059/kpi-minta-kemkominfoevaluasi-ipp-metro-tv-dan-tv-one/0/berita_satker

Barker, C. (2014). Kamus kajian budaya. Kanisius.

Biagi, S. (2010). Media impact (M. Irfan \& W. W. Mahendra (eds.)). Salemba Humanika. 
Butler, J. (2019). The visual experience of accessing captioned television and digital videos. Television $\mathcal{E}$ New Media, 21(7), 679-696. https://doi.org/ https://doi.org/10.1177/1527476418824805

Change.org. (2014). Cabut izin penyiaran TV One. Change.Org. https://www. change.org/p/kpi-pusat-menkominfo-cabut-izin-penyiaran-tv-one

Edgerton, G. R., \& Rollins, P. C. (2001). Television histories: shaping collective memory in the media age. Kentucky University Press.

Gans, H. J. (2004). Democracy and the news. Oxford University.

Heryanto, A. (2015). Identitas dan kenikmatan: Politik budaya layar Indonesia. Kepustakaan Populer Gramedia.

Hill, D. T. (2011). The press in new order. Yayasan Obor.

Indonesian General Election of Law, No. 7 (2017).

Jati, W. R. (2013). Media and political persuasion: The role of media in Indonesia presidential campaign 2001-2009. Jurnal Penelitian Politik, 10(2), 15-30. https://doi.org/https://doi.org/10.14203/jpp.v10i2.432

Kolstad, I; \& Wiig, A. (2016). Education and electoral participation: Reported versus actual voting behaviour. Applied Economics Letters, 23(13), 908-911. https://doi.org/https://doi.org/10.1080/13504851.2015.1119785

Kovack, B., \& Rosenstiel, T. (2001). The elements of journalism: What newspeople should know and the publik should expect. Crown Publisher.

Kurtbaş, İ. (2015). The factors influencing voting preferences in local elections " an empirical study". International Journal of Humanities and Social Science, 9(1), 197-210. http://www.ijhssnet.com/journals/Vol_5_No_9_1_ September_2015/18.pdf

Laksono, S. M. (2016). Sepuluh televisi setelah tujuh komitmen. Kpi.go.Id, 25 Oktober 2016. http://kpi.go.id/index.php/id/umum/16-kajian/33623. sepuluh-televisi-setelah-tujuh-komitmen

Mayer, A. K. (2011). Does education increase political participation? The Journal of Politics, 73(03), 633-645. https://doi.org/10.1017/S002238161100034X

Mcquail, D. (2011). Teori komunikasi massa (6th ed.). Salemba Humanika.

Mursito. (2012). Realitas media. Smart Media.

Nimmo, D. (2000). Political communication and public opinion in America (T. Surjaman (ed.)). Rosdakarya.

Nur, R., Taufik, A., \& Tahir, M. (2015). Perilaku politik pemilih pemula dalam 
pelaksanaan pemilihan presiden 2014 di Desa Kanaungan Kecamatan Labakkang Kabupaten Pangkep. Jurnal Otoritas, 5(1), 91-106. https:// doi.org/10.26618/ojip.v5i1.116

Pawito. (2009). Komunikasi politik, media massa dan kampanye pemilihan. Jalasutra. Persson, M. (2015). Education and political participation. British Journal of Political Science, 45(3), 689-703. https://doi.org/10.1017/S0007123413000409

Purwasito, A. (2011). Pengantar studi politik. UNS Press.

Surjomiharjo, A. (2002). Beberapa segi perkembangan sejarah pers di Indonesia. Kompas Gramedia.

Suseno, F. M. (2002). Etika politik. Gramedia.

Suwardi, P. (2006). Seputar bisnis dan produksi siaran televisi. TVRI.

Tamburaka, A. (2012). Agenda setting media massa. Rajawali Press.

Visser, M. (1998). Five theories of voting action. https://ris.utwente.nl/ws/ portalfiles/portal/6078399/t0000001.pdf

Widarini, D. A., Saefullah, H. M., Nilamsari, N., Andriani, F., \& Wiyati, E. K. (2019). Kepercayaan publik terhadap pers media arus utama. https:// dewanpers.or.id/assets/ebook/jurnal/1912180757_Laporan_Ahir_1_ November_2019_Edit(1).pdf

Widiastuti, T. (2016). Kepemilikan media dan demokrasi di era informasi digital. Indocompac, 763-776. https://media.neliti.com/media/ publications/172080-ID-kepemilikan-media-dan-demokrasi-di-era-d.pdf

Winchester, T. M., Binney, W., \& Hall, J. (2014). Young adults and politics: Investigating factors influencing voter decision making. Journal of Nonprofit $\mathcal{E}$ Public Sector Marketing, 26(3), 226-257. https://doi.org/10.10 $80 / 10495142.2014 .915635$

www.detik.com. (2017). Dewan Pers: Jurnalis harus jaga integritas dan nilai etik profesi. 9 Feb 2017, Pkl 12.18. https://news.detik.com/berita/d-3417778/ jurnalis-harus-jaga-integritas-dan-nilai-etik-profesi

Yandry, K. (2017). The politics of securitization in democratic Indonesia. Palgrave Macmillan. 
Journal of Social Studies (JSS), Volume 17, Number 1, 2021: 79-94 